\title{
Regression models for estimating leaf area of seedlings and adult individuals of Neotropical rainforest tree species
}

\author{
E. Brito-Rocha ${ }^{a}$, A. C. Schilling ${ }^{b}$, L. Dos Anjos ${ }^{a}$, D. Piotto ${ }^{c}$, A. C. Dalmolin ${ }^{a}$ and M. S. Mielke ${ }^{a}$ \\ ${ }^{a}$ Departamento de Ciências Biológicas, Universidade Estadual de Santa Cruz - UESC, \\ Rodovia Jorge Amado, Km 16, CEP 45662-900, Ilhéus, BA, Brazil

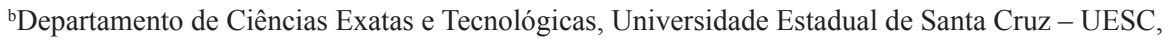 \\ Rodovia Jorge Amado, Km 16, CEP 45662-900, Ilhéus, BA, Brazil \\ ${ }^{\mathrm{c}}$ Centro de Formação em Ciências e Tecnologias Agroflorestais, Universidade Federal do Sul da Bahia - UFSB, \\ BR 415, Km 39, CEP 45613-204, Itabuna, BA, Brazil \\ *e-mail: msmielke@uesc.br
}

Received: March 28, 2015 - Accepted: September 15, 2015 - Distributed: November 30, 2016

(With 1 figure)

\begin{abstract}
Individual leaf area (LA) is a key variable in studies of tree ecophysiology because it directly influences light interception, photosynthesis and evapotranspiration of adult trees and seedlings. We analyzed the leaf dimensions (length $-\mathrm{L}$ and width - W) of seedlings and adults of seven Neotropical rainforest tree species (Brosimum rubescens, Manilkara maxima, Pouteria caimito, Pouteria torta, Psidium cattleyanum, Symphonia globulifera and Tabebuia stenocalyx) with the objective to test the feasibility of single regression models to estimate LA of both adults and seedlings. In southern Bahia, Brazil, a first set of data was collected between March and October 2012. From the seven species analyzed, only two ( $P$. cattleyanum and T. stenocalyx) had very similar relationships between LW and LA in both ontogenetic stages. For these two species, a second set of data was collected in August 2014, in order to validate the single models encompassing adult and seedlings. Our results show the possibility of development of models for predicting individual leaf area encompassing different ontogenetic stages for tropical tree species. The development of these models was more dependent on the species than the differences in leaf size between seedlings and adults.
\end{abstract}

Keywords: leaf allometry, leaf size, leaf shape, ontogenetic stage, tree growth.

\section{Modelos de regressão para estimativa da área foliar de indivíduos jovens e adultos de espécies arbóreas de floresta neotropical}

\begin{abstract}
Resumo
Área foliar individual (AF) é uma variável chave em estudos sobre a ecofisiologia de arbóreas, porque influencia diretamente a interceptação de luz, a fotossíntese e a evapotranspiração das árvores adultas e das mudas. Foram analisadas as dimensões foliares (comprimento - C e largura - L) de indivíduos adultos e de mudas de sete espécies arbóreas de florestas neotropicais (Brosimum rubescens, Manilkara maxima, Pouteria caimito, Pouteria torta, Psidium cattleyanum, Symphonia globulifera e Tabebuia stenocalyx), com o objetivo de testar a viabilidade de modelos de regressão linear para estimar a AF de indivíduos adultos e mudas. No sul da Bahia, Brasil, um primeiro conjunto de dados foi coletado entre março e outubro de 2012. A partir das sete espécies analisadas, apenas duas (P. cattleyanum e T. stenocalyx) apresentaram relações muito semelhantes entre e AF e CL, em ambos os estádios ontogenéticos. Para estas duas espécies, um segundo conjunto de dados foi coletado em agosto de 2014, a fim de validar os modelos únicos que englobam folhas de indivíduos adultos e mudas. Nossos resultados mostram a possibilidade de desenvolvimento de modelos para a predição da área foliar, abrangendo diferentes estádios ontogenéticos para espécies arbóreas tropicais. O desenvolvimento destes modelos foi mais dependente das espécies do que das diferenças entre o tamanho das folhas de mudas e de indivíduos adultos.
\end{abstract}

Palavras-chave: alometria foliar, tamanho da folha, formato da folha, estádio ontogenético, crescimento arbóreo.

\section{Introduction}

Individual leaf area (LA) is a key variable in forest ecophysiological studies, because it directly influences light interception, photosynthesis and evapotranspiration of adult trees, saplings and seedlings (Niinemets, 2010; Zhang and Pan, 2011). Furthermore, LA is an important variable for seedling establishment and for sun/shade 
acclimation of tropical rainforest tree species (Varone and Gratani, 2009; Coste et al., 2011; Houter and Pons, 2012; Laurans et al., 2012). The direct determination or estimation of LA is of great importance to evaluate the performance of seedlings in tree plantations and in natural forests (Coste et al., 2011; Houter and Pons, 2012; Laurans et al., 2012). The methods used for LA estimation can be either destructive or nondestructive. Destructive methods involve leaf harvesting, which can be done using automated leaf area meters, photocopies, planimeters (Tsuda, 1999) and softwares that calculate LA based on scanned images and digital photos (O'Neal et al., 2002; Godoy et al., 2007; Toebe et al., 2010). Nondestructive methods do not require leaf destruction and are based on regression models to estimate LA from leaf linear dimensions, as length (L) and width (W) (Kandiannan et al., 2002; Antunes et al., 2008; Rouphael et al., 2010; Zhang and Pan, 2011; Pompelli et al., 2012; Souza and Habermann, 2014).

Depending on the objective of the study, destructive methods can be more advantageous than nondestructive ones. For example, from a practical point of view, destructive methods that use leaf $\mathrm{x}$ area meters are the fastest among all, enabling assessment of a large number of leaves within a short time (Tsuda, 1999). In addition, scanned images and digital photographs allow the construction of image banks, which can then be used, for example, for studies aiming to analyze the color and shape of the leaves. On the other hand, the development of regression models to estimate LA based on easily measured variables is a practical and fast methodology for using at the field. The regression models make possible to obtain reliable estimates of individual leaf areas using simple tools, as ruler and calculator. This implies the possibility to analyze the development of a single leaf and prevents loss of photosynthetic leaf surface and the resulting energy cost used in the formation of plant tissues.

Regression models encompassing seedlings and adults for estimate LA may be useful in field studies of ecology and ecophysiology of tropical tree species, such as studies focused on differences in the herbivory rate between seedlings and adults (Boege and Marquis, 2005) and differences in the leaf development and photosynthetic behavior between seedlings and adults (Ishida et al., 2005). It is especially important in highly biodiverse forests, as the Neotropical rainforests (Thomas, 1999), where the large number of species requires the development of numerous models for the prediction of species-specific individual leaf areas. However, the development of a single regression model to estimate LA of seedlings and adults may not be appropriate because of the biological characteristics of tree species. First, seedlings of the same tree species have inherently smaller individual leaf areas than adults, because they have smaller size (Ishida et al., 2005). Second, many species have differences in leaf morphological traits between leaf seedlings, saplings and adults, which is related to the regeneration niche (Thomas and Ickes, 1995; Ishida et al., 2005; Houter and Pons, 2012). Even though there are many references of regression models in the literature for predicting of LA in tropical tree species (Antunes et al., 2008; Zhang and Pan, 2011; Pompelli et al., 2012; Souza and Habermann, 2014), we are aware of no published studies aiming to compare regression models developed for both seedlings and adult individuals of tropical trees.

In this study, we analyzed leaf dimensions of seedlings and adults of seven Neotropical rainforest tree species with the objective to test the feasibility of single regression models to estimate LA of both adults and seedlings. We hypothesize that integrative predictive models for both ontogenetic stages provide similar adjustments compared to single models for each ontogenetic stage despite differences in leaf size between seedlings and adults.

\section{Material and Methods}

We analyzed the leaf dimensions of seedlings and adults from seven native species of southern Bahia, Brazil. Species were chosen based on their morphological characteristics, natural distribution, and phylogeny. The selected species have simple leaves, broad distribution in the Neotropics, and belong to five botanical families (Table 1).

Leaves were collected in the Floresta Viva Institute nursery, Serra Grande, Uruçuca, Bahia, Brazil, from March to October 2012. The leaves collected were all fully expanded, had their edges preserved and did not show herbivory or disease symptoms. For seedlings, 50 leaves were randomly collected from the same number of individuals (one leaf fully expanded and a mature leaf per plant). Seedlings were growing at the nursery of Floresta Viva Institute under 50\% artificial shading. They were chosen for the study based on the presence of at least six fully expanded leaves and height between 0.15 and $0.25 \mathrm{~m}$. For adults, 50 leaves, for

Table 1. List of the seven studied species with their scientific names, family and age of seedlings grown in the Floresta Viva Institute nursery, Serra Grande, Bahia, Brazil.

\begin{tabular}{lcc}
\hline \multicolumn{1}{c}{ Species } & Family & Age (weeks) \\
\hline Brosimum rubescens Taub. & Moraceae & 52 \\
Manilkara maxima T.D. Penn. & Sapotaceae & 56 \\
Pouteria caimito (Ruiz \& Pav.) Radlk. & Sapotaceae & 16 \\
Pouteria torta (Mart.) Radlk. & Sapotaceae & 16 \\
Psidium cattleyanum Sabine & Myrtaceae & 30 \\
Symphonia globulifera L. f. & Clusiaceae & 10 \\
Tabebuia stenocalyx Sprague \& Stapf & Bignoniaceae & 48 \\
\hline
\end{tabular}


species, were randomly collected from three to six trees of different sizes. The criterion used to select the adult individuals sampled was sexual maturity, ensuring that all plants were adults. Leaves were collected from different parts of the interior and top of the tree, in order to obtain greater morphological variability for sampling.

Harvested leaves were taken to the Plant Physiology Laboratory of the Universidade Estadual de Santa Cruz (UESC), Ilhéus, Bahia, Brazil, where they were washed and dried with paper towel, and had the image of the adaxial leaf surface digitalized. For leaves with length less than $35 \mathrm{~cm}$, images of the adaxial leaf surface were scanned using a desktop scanner (HP Scanjet 2400 scanner), and digitalized in TIFF format with 100 dpi resolution. For leaves with length greater than $35 \mathrm{~cm}$, adaxial leaf surface was photographed with a digital camera (Sony Alpha 200), and saved in JPEG format with 72 dpi resolution. A wooden white plate covered with an anti-reflective glass was used as the background of the photos. In the corner of the plate, a figure of a black cardboard, with an area of $36 \mathrm{~cm}^{2}$ $(6 \mathrm{~cm} \times 6 \mathrm{~cm})$, was fixed to calibrate the image scale. Images were then analyzed using the free software ImageJ (Abramoff et al., 2004). For each leaf, the leaf length (L), maximum leaf width $(\mathrm{W})$ and LA were measured.

To determine the feasibility of using a single model for seedlings and adults of the same species, we performed an analysis of covariance (ANCOVA), comparing values in terms of a categorical variable with two levels. The use of a single model was chosen when there was no significant difference $(p>0.10)$ between the models for each of the ontogenetic stages (Logan, 2010).

The models for predicting LA were obtained by linear regression analysis, considering as dependent variable the observed LA and as independent variables the leaf linear dimensions $\left(\mathrm{L}^{2}\right.$ and $\left.\mathrm{W}^{2}\right)$ and the product $\mathrm{LW}$. Individual models were developed for each of the species and ontogenetic stages (seedlings and adults). The coefficient of determination $\left(\mathrm{R}^{2}\right)$ was used as a measure of goodness-of-fit. Also, to assess the goodness-of-fit of the equations, the relative root mean square errors (RRMSE, \%) were calculated dividing the root of mean square errors (RMSE) by the mean values of measured leaf areas, and multiplying the resulting value by 100 (Richardson et al., 2002). The predictive performance of the regression models were validated using the cross-validation method (Efron and Tibshirani, 1993). For this, the data was randomly divided into $\mathrm{k}$ groups (in this work we used $\mathrm{k}=10$ ) and the model was adjusted $\mathrm{k}$ times, so that each time one of $\mathrm{k}$ groups is used as a test set for the model that was adjusted with corresponding training sets (the remaining $\mathrm{n}-\mathrm{k}$ data division of each data set). It was expected that the estimate of the prediction error obtained by cross-validation based on model adjustment with only a portion of the data is greater than the estimated error in the model, when all observations are used in the fit. The relative difference between the error of the full model and the estimated error of the cross-validation (prediction error PE) represents a measure of the predictive accuracy of the fitted model (Maindonald and Braun, 2003).

For the species in which it was possible to obtain single models for the two ontogenetic stages, the models were validated using a second sample of leaves collected in the same place, but from different plants and seedling lots, in August 2014. The validation of the models was done plotting the values of predicted (PLA) and observed (OLA) values of LA. In addition, the relative root mean square calibration errors (RRMSEc, \%) were calculated for seedlings and adults. The values of RRMSEc were calculated dividing the root of mean square calibration errors (RMSEc) of the OLA and PLA by the mean values of OLA, and multiplying the resulting value by 100 (Richardson et al., 2002).

\section{Results}

For all species, the average values of $\mathrm{L}, \mathrm{W}$ and $\mathrm{LA}$ were significantly higher in adults than in seedlings $(\mathrm{p}<0.01$, t-test, Table 2). Leaves of $T$. stenocalyx and $P$. torta showed

Table 2. Mean values (minimum - maximum) of maximum leaf length (L), width (W), leaf area (LA) and leaf shape (L:W) for seedlings and adults of seven rainforest tree species. Ontogenetic stage (OS): A - adult, $\mathrm{S}-$ seedling $(\mathrm{n}=50)$.

\begin{tabular}{lccccl}
\hline \multicolumn{1}{c}{ Species } & OS & $\mathbf{L}(\mathbf{c m})$ & $\mathbf{W}(\mathbf{c m})$ & \multicolumn{1}{c}{$\mathbf{L A}\left(\mathbf{c m}^{2}\right)$} & $\mathbf{L}: \mathbf{W}$ \\
\hline B. rubescens & A & $11.95(8.72-16.67)^{*}$ & $5.66(3.96-8.18)^{*}$ & $45.47(22.37-93.55)^{*}$ & $2.13(1.87-2.37)$ \\
& S & $6.45(4.10-10.30)$ & $2.31(1.30-3.70)$ & $11.37(4.25-20.96)$ & $2.79(2.50-3.15)^{*}$ \\
M. maxima & A & $9.05(6.87-12.47)^{*}$ & $3.84(2.81-5.53)^{*}$ & $24.48(13.57-46.18)^{*}$ & $2.37(2.05-2.63)^{*}$ \\
& S caimito & $6.63(4.52-12.35)$ & $3.14(2.19-4.57)$ & $14.82(7.13-37.46)$ & $2.11(1.59-2.79)$ \\
& A & $9.89(6.52-13.11)^{*}$ & $3.45(2.30-4.78)^{*}$ & $24.70(11.08-44.11)^{*}$ & $2.88(2.25-3.60)$ \\
P. torta & S & $8.09(4.98-12.65)$ & $2.18(1.27-3.30)$ & $12.84(4.83-28.22)$ & $3.73(2.80-4.72)^{*}$ \\
& A & $26.41(17.23-39.16)^{*}$ & $7.73(4.32-10.84)^{*}$ & $138.79(52.92-252.43)^{*}$ & $3.43(2.83-4.35)^{*}$ \\
P. cattleyanum & S & $9.08(7.17-11.64)$ & $4.24(3.44-5.22)$ & $25.55(17.34-39.79)$ & $2.18(1.76-2.51)$ \\
S. globulifera & A & $9.80(6.86-12.71)^{*}$ & $5.05(3.42-6.21)^{*}$ & $34.49(17.48-53.82)^{*}$ & $1.95(1.59-2.42)$ \\
& S & $6.19(2.85-7.93)$ & $2.85(1.47-3.96)$ & $12.59(2.97-21.27)$ & $2.18(1.81-2.69)^{*}$ \\
T. stenocalyx & A & $7.25(5.69-8.89)^{*}$ & $2.97(1.90-3.95)^{*}$ & $14.60(7.40-23.68)^{*}$ & $2.46(1.99-3.08)$ \\
& S & $6.75(4.37-8.84)$ & $2.26(1.78-2.80)$ & $9.79(5.24-15.25)$ & $2.99(2.41-3.94)^{*}$ \\
& A & $31.64(18.91-47.12)^{*}$ & $12.38(6.70-20.15)^{*}$ & $277.24(88.65-617.99)^{*}$ & $2.60(1.73-3.57)$ \\
& S & $8.36(5.14-15.29)$ & $2.53(1.42-3.71)$ & $13.47(4.60-35.83)$ & $3.30(2.62-4.29)^{*}$ \\
\hline
\end{tabular}

*Indicate statistically significant difference between adult and seedling ontogenetic stages at $\mathrm{p}<0.01$, t-test. 
the highest values of L, W and LA for adults. For seedlings, the highest values of $\mathrm{L}, \mathrm{W}$ and LA were exhibited by $P$. torta. The smallest values of $\mathrm{L}, \mathrm{W}$ and $\mathrm{LA}$ were found in the leaves of $B$. rubescens, $P$. caimito and $S$. globulifera, respectively. The highest and smallest differences of the measured values of L, W and LA between adults and seedlings were observed for T. stenocalyx and S. globulifera, respectively. For T. stenocalyx, the mean values of L, W and LA were respectively 3.8, 4.9 and 20.6-fold higher in adults than seedlings. In contrast, for $S$. globulifera the mean values of L, W and LA were respectively, 1.1-, 1.3- and 1.5-fold higher

Table 3. Species, values of p-interaction and p-level (ANCOVA) for leaves of seedling and adult individuals $(\mathrm{n}=100)$.

\begin{tabular}{lccc}
\hline \multicolumn{1}{c}{ Species } & & p-interaction & p-level \\
\hline B. rubescens & LW & 0.101 & 0.000 \\
& $\mathrm{~L}^{2}$ & 0.000 & - \\
& $\mathrm{W}^{2}$ & 0.000 & - \\
M. maxima & $\mathrm{LW}$ & 0.409 & 0.021 \\
& $\mathrm{~L}^{2}$ & 0.003 & - \\
& $\mathrm{W}^{2}$ & 0.407 & 0.000 \\
P. caimito & $\mathrm{LW}$ & 0.106 & 0.000 \\
& $\mathrm{~L}^{2}$ & 0.000 & - \\
P. torta & $\mathrm{W}^{2}$ & 0.000 & - \\
& $\mathrm{LW}$ & 0.805 & 0.072 \\
& $\mathrm{~L}^{2}$ & 0.339 & 0.020 \\
P. cattleyanum & $\mathrm{W}^{2}$ & 0.050 & 0.000 \\
& $\mathrm{LW}^{2}$ & 0.239 & 0.276 \\
& $\mathrm{~L}^{2}$ & 0.246 & 0.000 \\
S. globulifera & $\mathrm{W}^{2}$ & 0.021 & - \\
& $\mathrm{LW}^{2}$ & 0.000 & - \\
& $\mathrm{L}^{2}$ & 0.000 & - \\
& $\mathrm{W}^{2}$ & 0.002 & - \\
& $\mathrm{LW}^{\text {. stenocalyx }}$ & 0.566 & 0.386 \\
& $\mathrm{~L}^{2}$ & 0.438 & 0.156 \\
& $\mathrm{~W}^{2}$ & 0.600 & - \\
\hline & & &
\end{tabular}

in adults than seedlings. Leaf shapes $(\mathrm{L}: \mathrm{W})$ varied from 1.95 ( . cattleyanum, adults) to 3.73 (P. caimito, seedlings). The L:W ratio was higher in seedlings than in adults for most species, with exception of M. maxima and $P$. torta. The highest difference between adults and seedlings for $\mathrm{L}: \mathrm{W}$ was obtained for $P$. torta (adult/seedling $=1.57$ ) and the smallest difference for $M$. maxima and $P$. cattleyanum (adult/seedling $=1.12)$.

The use of a single model for both ontogenetic stages (seedling and adult) was possible only for two species (P. cattleyanum and T. stenocalyx) (Table 3 ). The single model based on the product LW showed the high values of $\mathrm{R}^{2}(>0.99)$, followed by the RRMSE below $6.0 \%$ and $\mathrm{PE}$ below $7.0 \%$, are indicatives of the high accuracy of this models (Table 3). For T. stenocalyx, a single model also proved feasible based on $\mathrm{L}^{2}$, but the RRMSE and $\mathrm{PE}$ values are higher than $35 \%$ and $16 \%$, respectively (Table 4). For the two species, only the models based on LW were tested against a new set of leaves (Table 5). When the predicted (PLA) and observed (OLA) values of LA from a new set of leaves were plotted, high values of $\mathrm{R}^{2}$ and low RRMSEc were observed for both species (Figure 1, Table 5).

\section{Discussion}

Seedlings of the same tree species have smaller LA than adults because they have smaller size. As expected, the values of leaf dimensions (L, W and LA) were much higher in adults than in seedlings for all the seven species analyzed in our study. Moreover, the differences between average values of LA for adults and seedlings of T. stenocalyx and M. maxima indicate a large variation in the leaf dimensions among tree species according to the ontogenic stage. Ishida et al. (2005), for instance, found that LA of adult individuals of Macaranga gigantea was around 10 times higher than seedlings; an intermediate value between the extremes found in our study.

Compared with L, W and LA, very small differences were observed between seedlings and adults for the average

Table 4. Integrative models for leaves of seedling and adult individuals of $P$. cattleyanum and $T$. stenocalyx, with their $\mathrm{R}^{2}$, p-values, RRMSE and PE $(\mathrm{n}=100)$.

\begin{tabular}{lcccccc}
\hline \multicolumn{1}{c}{ Species } & & Model & $\mathbf{R}^{2}$ & p & RRMSE (\%) & PE (\%) \\
\hline P. cattleyanum & LW & LA $=-0.08+0.69 \mathrm{LW}$ & 0.99 & 0.000 & 2.68 & 5.80 \\
T. stenocalyx & LW & LA $=-2.07+0.69 \mathrm{LW}$ & 0.99 & 0.000 & 5.98 & 6.36 \\
& L $^{2}$ & LA $=-3.64+0.27 \mathrm{~L}^{2}$ & 0.95 & 0.000 & 35.25 & 16.98 \\
\hline
\end{tabular}

Table 5. Relationships between predicted (PLA) and observed (OLA) leaf areas for seedlings and adults trees of P. cattleyanum and T. stenocalyx. The models used to calculate PLA are in Table 4.

\begin{tabular}{ccccccc}
\hline Species & OS & Age (weeks) & n & Equation & R $^{\mathbf{2}}$ & RRMSEc (\%) \\
\hline P. cattleyanum & S & 30 & 80 & PLA $=0.17+1.03$ OLA & 0.99 & 6.44 \\
& A & - & 76 & PLA $=0.32+0.99$ OLA & 0.99 & 2.63 \\
& All & - & 156 & PLA $=0.51+0.98$ OLA & 0.99 & 3.50 \\
T. stenocalyx & S & 48 & 63 & PLA $=-1.63+1.12$ OLA & 0.99 & 9.03 \\
& A & - & 56 & PLA $=-1.39+1.03$ OLA & 0.97 & 6.07 \\
& All & - & 119 & PLA $=-0.11+1.03$ OLA & 0.99 & 9.09 \\
\hline
\end{tabular}


(a)

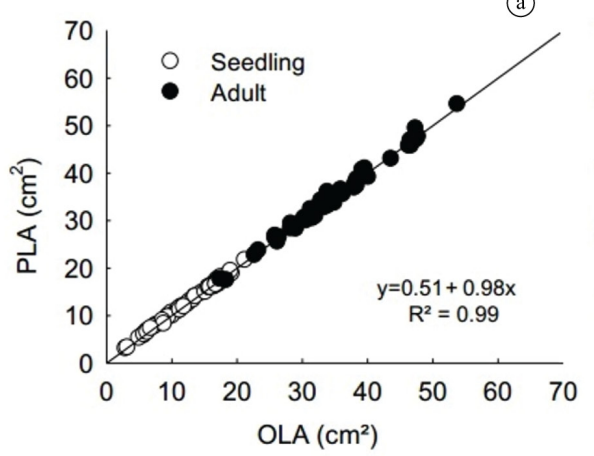

(b)

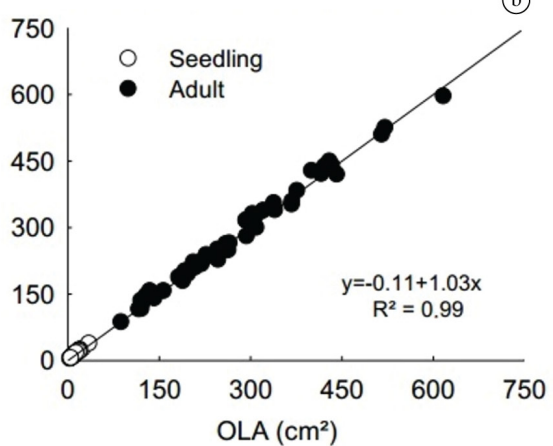

Figure 1. Relationships between predicted (PLA) and observed (OLA) leaf areas for seedlings and adults trees of P. cattleyanum (a) and T. stenocalyx (b). Solid line represent the 1:1 relationship between PLA and OLA. The models used to calculate PLA are in Table 4.

values of L:W. We are unaware of published studies reporting differences of $\mathrm{L}: \mathrm{W}$ between seedlings and adults for tropical trees. Comparing new and old leaves of eight evergreen subtropical trees in China, Zhang and Pan (2011) reported values of $\mathrm{L}: \mathrm{W}$ very close of those we obtained in our study. It is noteworthy that in our study, only two of the seven species ( $M$. maxima and $P$. torta) had values of L:W greater in adults than in seedlings. In addition, between the two species of the genus Pouteria, the values of $\mathrm{L}: \mathrm{W}$ ratio are opposed. The average value of $\mathrm{L}: \mathrm{W}$ was higher in seedlings than in adults for P. torta, and higher in seedlings than in adults for $P$. caimito. As an indicative of the leaf shapes, the average values of L:W in our study indicate that all leaves tends to have elliptical shapes, as the average values for adults and seedlings were, respectively, 2.5 and 2.8. These values are very close of those reported by Zhang and Pan (2011) and higher than the values obtained by Rouphael et al. (2010) for Rosa hybrida. Moreover, the ratios between adults and seedlings for L:W in our study were low and much smaller than the differences obtained for LA. In this study, the differences between adults and seedlings for L:W ranged from 1.1, for M. maxima and P. cattleyanum, to 1.6 , for $P$. torta.

There are several published studies of nondestructive estimations of LA involving measurements of leaf dimensions as independent variables, but using different regression models, including power (Kandiannan et al., 2002; Antunes et al., 2008; Pompelli et al., 2012; Wang and Zhang, 2012; Misle et al., 2013) and second-order polynomial models (Mazzini et al., 2010). In our study, we adopted the use of linear regression models because they are simpler and provide good estimates for a great number of plant species with different leaf areas and leaf shapes when compared with non-linear regression models (Cristofori et al., 2007; Mazzini et al., 2010; Rouphael et al., 2010; Wang and Zhang, 2012; Souza and Habermann, 2014). In addition, we tested two geometric formulas for estimating LA from simple linear regression models. Initially, we attempted to use simple linear measurements (L and $\mathrm{W})$, based on the square area formula $\left(\mathrm{L}^{2}\right.$ and $\left.\mathrm{W}^{2}\right)$.
This approach was tested with the purpose of reducing the effort for field measurements. Using only a single linear measurement ( $\mathrm{L}$ or $\mathrm{W}$ ) the time needed for field measurements is half of what is needed considering two linear measurements ( $\mathrm{L}$ and $\mathrm{W}$ ). The second approach was the use of the rectangle area $(\mathrm{L} \times \mathrm{W})$. Although more time and effort is needed for collecting data, the use of the rectangle area (LW) showed better adjustments for predicting LA. These results were closely related with the leaf shapes, as the values of the inclinations were about 0.7 for $\mathrm{L} \times \mathrm{W}$ and 0.3 for $\mathrm{L}^{2}$ and $\mathrm{W}^{2}$.

The use of a single model, regardless of the plant ontogenetic stage, may represent less work and high reliability. For instance, leaves of T. stenocalyx showed the highest differences in L, W and LA between adults and seedlings, compared to the other species. The average LA of adults was almost 21-fold higher than seedlings. The highest and smallest measured values of LA in seedlings and adults of this species were $35.8 \mathrm{~cm}^{2}$ and $88.7 \mathrm{~cm}^{2}$, respectively. Moreover, the difference between adults and seedlings for L:W was exactly the average found for the set of all seven species (1.3). Therefore, the development of simple predictive models for LA for both ontogenetic stages seems to be more dependent on the species than the differences in leaf size between seedlings and adults.

The development of regression models encompassing different ontogenetic stages for tropical tree species may have numerous practical advantages in field studies of ecology and ecophysiology of tropical trees. However, in tropical rainforests, seedlings, saplings and adults can vary widely in leaf shape and leaf areas (Thomas and Ickes, 1995; Ishida et al., 2005; Houter and Pons, 2012). Our results demonstrate that it is not always possible to use models developed for adults in studies with seedlings, and vice-versa. This fact is very critical, since most of the models available in the literature have been developed based upon leaves of adult plants (Cristofori et al., 2007; Mazzini et al., 2010; Rouphael et al., 2010; Wang and Zhang, 2012; Souza and Habermann, 2014). The use of models developed with leaves of adults in studies with 
seedlings can cause serious errors in the data analysis and interpretation. Furthermore, in this study, we only test square-based $\left(\mathrm{L}^{2}, \mathrm{~W}^{2}\right)$ and rectangular $(\mathrm{L} \times \mathrm{W})$ formulas and adopted adjustments based on simple linear regression models. Considering the changes in the leaf shapes due to ontogenetic changes, we also encourage the development of further studies, involving a larger number of species with different geometric equations and regression formulas.

In summary, our results indicate that from the seven species analyzed, only two ( $P$. cattleyanum and T. stenocalyx) had very similar relationships between LW and LA in both ontogenetic stages. Our study shows that it is possible to develop predictive models for estimating leaf area encompassing different ontogenetic stages for tropical trees, but the reliability of these models depends more on the species itself than the differences in leaf size between seedlings and adults.

\section{Acknowledgements}

We thank Gerson J. Sales Neto, Nilson A. dos Santos and Rones F. Souza of Floresta Viva Institute for assistance with data collection. We also thank Dr. Maria C. Sanches of Universidade Federal de Uberlândia for her helpful suggestions on the manuscript. Funding for Ediófila B. Rocha during this study was provided by a scholarship from Capes (Brazilian Higher Education Council). The corresponding author gratefully acknowledges $\mathrm{CNPq}$ (Brazilian National Council for Scientific and Technological Development), Brazil, for the award of a fellowship of scientific productivity. This study was supported by CNPq (Proc. 561933/2010-3).

\section{References}

ABRAMOFF, M.D., MAGALHAES, P.J. and RAM, S.J., 2004. Image Processing with ImageJ. Biophotonics International, vol. 11 , no. 7 , pp. 36-42.

ANTUNES, W.C., POMPELLI, M.F., CARRETERO, D.M. and DAMATTA, F.M., 2008. Allometric models for non-destructive leaf area estimation in coffe (Coffea arabica and Coffea canephora). Annals of Applied Biology, vol. 153, no. 1, pp. 33-40. http://dx.doi. org/10.1111/j.1744-7348.2008.00235.x.

BOEGE, K. and MARQUIS, R.J., 2005. Facing herbivory as you grow up: the ontogeny of resistance in plants. Trends in Ecology \& Evolution, vol. 20, no. 8, pp. 441-448. http://dx.doi. org/10.1016/j.tree.2005.05.001. PMid:16701415.

COSTE, S., ROGGY, J.C., SCHIMANN, H., EPRON, D. and DREYER, E., 2011. A cost-benefit analysis of acclimation to low irradiance in tropical rainforest tree seedlings: leaf life span and payback time for leaf deployment. Journal of Experimental Botany, vol. 62, no. 11, pp. 3941-3955. http://dx.doi.org/10.1093/ jxb/err092. PMid:21511904.

CRISTOFORI, V., ROUPHAEL, Y., MENDOZA-GYVES, E. and BIGNAMI, C., 2007. A simple model for estimating leaf area of hazelnut from linear measurements. Scientia Horticulturae, vol. 113, no. 2, pp. 221-225. http://dx.doi.org/10.1016/j.scienta.2007.02.006.
EFRON, B. and TIBSHIRANI, R.J., 1993. An introduction to the bootstrap. London: Chapman \& Hall.

GODOY, L.J.G., YANAGIWARA, R.S., BÔAS, R.L.V., BACKES, C. and LIMA, C.P., 2007. Análise da imagem digital para estimativa da área foliar em plantas de laranja "Pera". Revista Brasileira de Fruticultura, vol. 29, no. 3, pp. 420-424. http://dx.doi.org/10.1590/ S0100-29452007000300004.

HOUTER, N. and PONS, T.L., 2012. Ontogenetic changes in leaf traits of tropical rainforest trees differing in juvenile light requirement. Oecologia, vol. 169, no. 1, pp. 33-45. http://dx.doi. org/10.1007/s00442-011-2175-x. PMid:22038060.

ISHIDA, A., YAZAKI, K. and HOE, A.L., 2005. Ontogenetic transition of leaf physiology and anatomy from seedlings to mature trees of a rain forest pioneer tree, Macaranga gigantea. Tree Physiology, vol. 25, no. 5, pp. 513-522. http://dx.doi.org/10.1093/ treephys/25.5.513. PMid:15741149.

KANDIANNAN, K., KAILASAM, C., CHANDARAGIRI, K.K. and SANKARAN, N., 2002. Allometric model for leaf area estimation in black pepper (Piper nigrum L.). Journal Agronomy \& Crop Science, vol. 188, no. 2, pp. 138-140. http://dx.doi. org/10.1046/j.1439-037X.2002.00540.x.

LAURANS, M., MARTIN, O., NICOLINI, E. and VINCENT, G., 2012. Functional traits and their plasticity predict tropical trees regeneration niche even among species with intermediate light requirements. Journal of Ecology, vol. 100, no. 6, pp. 1440-1452. http://dx.doi.org/10.1111/j.1365-2745.2012.02007.x.

LOGAN, M., 2010. Biostatistical design and analysis using $R$ : a practical guide. Oxford: Wiley-Blackwell.

MAINDONALD, J. and BRAUN, J., 2003. Data analysis and graphics using $R$ : an example-based approach. Cambridge: Cambridge University Press.

MAZZINI, R.B., RIBEIRO, R.V. and PIO, R.M., 2010. A simple and non-destructive model for individual leaf area estimation in citrus. Fruits, vol. 65, no. 5, pp. 269-275. http://dx.doi.org/10.1051/ fruits/2010022.

MISLE, E., KAHLAOUI, B., HACHICHA, M. and ALVARADO, P., 2013. Leaf area estimation in muskmelon by allometry. Photosynthetica, vol. 51, no. 4, pp. 613-620. http://dx.doi. org/10.1007/s11099-013-0062-x.

NIINEMETS, Ü., 2010. A review of light interception in plant stands from leaf to canopy in different plant functional types and in species with varying shade tolerance. Ecological Research, vol. 25, no. 4, pp. 693-714. http://dx.doi.org/10.1007/s11284-010-0712-4.

O’NEAL, M.E., LANDIS, D.A. and ISAACS, R., 2002. An inexpensive, accurate method for measuring leaf area and defoliation through digital image analysis. Journal of Economic Entomology, vol. 95, no. 6, pp. 1190-1194. http://dx.doi.org/10.1603/00220493-95.6.1190. PMid:12539831.

POMPELLI, M.F., ANTUNES, W.C., FERREIRA, D.T.R.G., CAVALCANTE, P.G.S., WANDERLEY-FILHO, H.C.L. and ENDRES, L., 2012. Allometric models for non-destructive leaf area estimation of Jatropha curcas. Biomass and Bioenergy, vol. 36, pp. 77-85. http://dx.doi.org/10.1016/j.biombioe.2011.10.010.

RICHARDSON, A.D., DUIGAN, S.P. and BERLYN, G.P., 2002. An evaluation of noninvasive methods to estimate foliar chlorophyll content. The New Phytologist, vol. 153, no. 1, pp. 185-194. http://dx.doi.org/10.1046/j.0028-646X.2001.00289.x. 
ROUPHAEL, Y., MOUNEIMNE, A.H., ISMAIL, A., MENDOZADEGYVES, E., RIVERA, C.M. and COLLA, G., 2010. Modeling individual leaf area of rose (Rosa hybrida L.) based on leaf length and width measurement. Photosynthetica, vol. 48, no. 1, pp. 9-15. http://dx.doi.org/10.1007/s11099-010-0003-x.

SOUZA, M.C. and HABERMANN, G., 2014. Non-destructive equations to estimate the leaf area of Styrax pohliiand and Styrax ferrugineus. Brazilian Journal of Biology = Revista Brasileira de Biologia, vol. 74, no. 1, pp. 222-225. http://dx.doi.org/10.1590/15196984.17012. PMid:25055106.

THOMAS, S.C. and ICKES, K., 1995. Ontogenetic changes in leaf size in Malaysian Rain Forest Trees. Biotropica, vol. 27, no. 4, pp. 427-434. http://dx.doi.org/10.2307/2388954.

THOMAS, W.W., 1999. Conservation and monographic research on the flora of tropical America. Biodiversity and Conservation, vol. 8, no. 8, pp. 1007-1015. http://dx.doi.org/10.1023/A:1008857429787.

TOEBE, M., BRUM, B., LOPES, S.J., CARGNELUTTI-FILHO, A. and SILVEIRA, T.R., 2010. Estimativa da área foliar de Crambe abyssinica por discos foliares e por fotos digitais. Ciência Rural, vol. 40, no. 2, pp. 475-478. http://dx.doi.org/10.1590/S010384782010000200036 .

TSUDA, M., 1999. Errors in leaf area measurement with an automatic area meter due to leaf chlorophyll in crop plants. Annals of Botany, vol. 84, no. 6, pp. 799-801. http://dx.doi.org/10.1006/ anbo.1999.0984.

VARONE, L. and GRATANI, L., 2009. Leaf expansion in Rhamnus alaternus L. by leaf morphological, anatomical and physiological analysis. Trees (Berlin), vol. 23, no. 6, pp. 1255-1262. http:// dx.doi.org/10.1007/s00468-009-0365-5.

WANG, Z. and ZHANG, L., 2012. Leaf shape alters the coefficients of leaf area estimation models for Saussurea stoliczkai in central Tibet. Photosynthetica, vol. 50, no. 3, pp. 337-342. http://dx.doi. org/10.1007/s11099-012-0039-1.

ZHANG, L. and PAN, L., 2011. Allometric models for leaf area estimation across different leaf-age groups of evergreen broadleaved trees in a subtropical forest. Photosynthetica, vol. 49, no. 2, pp. 219-226. http://dx.doi.org/10.1007/s11099-011-0027-x. 